Please do not remove this page

RMIT

UNIVERSITY

\title{
Drivers and obstacles of outsourcing practices in China
}

Lau, Charles; Zhang, J

https://researchrepository.rmit.edu.au/esploro/outputs/9921861545101341/filesAndLinks?institution=61RMIT_INST\&index=null

Lau, C., \& Zhang, J. (2006). Drivers and obstacles of outsourcing practices in China. International Journal of Physical Distribution and Logistics Management, 36(10), 776-792.

https://doi.org/10.1108/09600030610714599

Published Version: https://doi.org/10.1108/09600030610714599

Repository homepage: https://researchrepository.rmit.edu.au

(c) Emerald Group Publishing Limited

Downloaded On 2023/04/26 19:37:19 +1000

Please do not remove this page 


\title{
Drivers and obstacles of outsourcing practices in China ${ }^{1}$
}

\author{
Kwok Hung Lau \\ Logistics and Supply Chain Discipline, School of Management, Royal Melbourne Institute of \\ Technology University, Melbourne, Australia, and \\ Jianmei Zhang \\ School of Management, Royal Melbourne Institute of Technology University, Melbourne, \\ Australia
}

\begin{abstract}
Purpose - To explore the key factors that motivate organizations in China to outsource and the obstacles these companies are facing in comparison with the situation in Western developed countries.

Design/methodology/approach - A case study approach was adopted with primary data collected through indepth interviews with six companies in China and secondary data aggregated from company reports and documents. Research findings were analyzed within and across all case studies to identify key drivers and obstacles of outsourcing.

Findings - Economic factor is a strong motivation for outsourcing in China, of which cost reduction, cost saving, and capital investment reduction are the main concerns. Strategic considerations, such as the use of outsourcing to accelerate re-engineering benefits, to focus on core competence, to increase flexibility, and to facilitate market penetration, are identified. Environmental factors like information technology (IT) development and capability of supplier can influence organizations' decisions to outsource. Meanwhile, companies in China have encountered obstacles and problems in the outsourcing process. They include the lack of capable service providers, loss of control, poor transportation and IT infrastructure, presence of local protection regulations, and lack of overall post-outsourcing measurement.

Originality/value - This paper presents a systematic exploration of the drivers and the obstacles of outsourcing in China and provides a framework that may guide business organizations to make better outsourcing decisions. It may assist organizations to clearly define their expectations, develop strategic outsourcing plans, and make appropriate decisions to achieve outsourcing objectives.
\end{abstract}

Keywords Outsourcing; Supply chain management; China

Paper type Research paper

\section{Introduction}

Outsourcing is a fast-growing aspect of the world economy with a worldwide spending of about US\$3.7 trillion in 2001 (Clott, 2004). According to the latest survey jointly conducted by Cap Gemini, Georgia Institute of Technology, SAP, and DHL, the use of third-party logistics (3PL) services continues to increase in Latin America, North America, South Africa, Western Europe, and Asia-Pacific. For the years 2002 to 2005, the average percentages of

\footnotetext{
${ }^{1}$ Citation:

Lau, C and Zhang, J 2006, 'Drivers and obstacles of outsourcing practices in China', International J ournal of Physical Distribution and Logistics Management, vol. 36, no. 10, pp. 776-792.
} 
usage in the five regions studied range from 67 to 84 percent (Cap Gemini et al., 2006). Another survey conducted by Lieb and Bentz (2004) reveals that 83 percent of the Fortune 500 manufacturers use 3PL services. Driven by globalization and rapid advance in information technology (IT), organizations strive to improve competitiveness and responsiveness to customer and market demands (Razzaque and Sheng, 1998). Outsourcing has increasingly become an important strategy that can significantly assist organizations to leverage their skills and resources to achieve greater competitiveness (Quinn and Hilmer, 1994; Welson, 1996).

As a fast-developing country, China has long been recognized as a popular place to outsource (Matteo, 2003). Low-cost labor and high-technology manufacturing have made China the leading destination for outsourcing (Brown, 2005). With its accession to the World Trade Organization (WTO), China is in more favorable conditions to implement its economic reform and industrial restructuring. This has stimulated the development of logistics industry and fostered a growing demand for outsourcing (Agarwal and $\mathrm{Wu}, 2004$ ). Nevertheless, the 3PL industry in China is still regarded to be in its infancy (Trunick, 2003). Although much has been written about outsourcing to China (Matteo, 2003; Brown, 2005; Forrest, 2005; Hannon, 2005), limited studies have been conducted to thoroughly investigate the key outsourcing drivers and problems that organizations in China have considered and encountered.

\section{Objectives of the Study}

Owing to the differences in economic and infrastructure development between developed and developing countries, it is likely that there will be different reasons for outsourcing in China that have yet to be determined. This study attempts to fill the gap in the literature by exploring the key factors that motivate organizations in China to outsource and the obstacles they are facing. Six case studies involving companies of different types of ownership are discussed to examine the strategic reasons of organizations in China for outsourcing and the problems they have encountered. A comparison between China and Western developed countries on the drivers and challenges of outsourcing is also presented.

\section{Literature Survey}

A large number of studies have analyzed the drivers of outsourcing from both a theoretical perspective (Trunick, 1989; Quinn and Hilmer, 1994; Razzaque and Sheng, 1998; Lankford and Parsa, 1999; Kakabadse and Kakabadse, 2000; Jennings, 2002; Lynch, 2004) and a practical point of view using case studies and surveys in developed countries such as US, UK, Australia, and New Zealand (Corbett, 1998; Fan, 2000; Bolumole, 2001; Al-Qirim, 2003; McIvor, 2003; Beaumont and Sohal, 2004; Kakabadse and Kakabadse, 2005). While many drivers are unique to specific organizations and industries, there are some common key factors that motivate organizations of all industries to make outsourcing decisions. These factors can broadly be categorized as economic, strategic, and environmental ones as summarized in Table I. By means of outsourcing, organizations can gain competitive advantage through cost reduction and improved responsiveness to changing business environment and market demand. 
Table I Drivers of outsourcing

\begin{tabular}{|c|c|c|}
\hline Economic factors & Objectives or anticipated outcomes & Authors \\
\hline Cost reduction & $\begin{array}{l}\text { - To improve profitability } \\
\text { - To improve operating efficiency } \\
\text { - To add value to product }\end{array}$ & $\begin{array}{l}\text { Trunick (1989), Richardson } \\
\text { (1990), Gonzales et al.(2005) }\end{array}$ \\
\hline Cost saving & $\begin{array}{l}\text { - To improve cash flow } \\
\text { - To increase efficiency }\end{array}$ & $\begin{array}{l}\text { Embleton and Wright (1998), } \\
\text { Claver et al. (2002) }\end{array}$ \\
\hline Capital investment reduction & $\begin{array}{l}\text { - To make capital funds more } \\
\text { available for core areas } \\
\text { - To improve return on assets } \\
\end{array}$ & $\begin{array}{l}\text { Corbett (1998), Razzaque and } \\
\text { Sheng (1998), Trunick (1998), } \\
\text { Lynch (2004) }\end{array}$ \\
\hline Strategic factors & Objectives or anticipated outcomes & Authors \\
\hline $\begin{array}{l}\text { Acceleration of business } \\
\text { process re-engineering }\end{array}$ & $\begin{array}{l}\text { - To improve performance } \\
\text { - To achieve competitive advantage }\end{array}$ & $\begin{array}{l}\text { Corbett (1998), Embleton and } \\
\text { Wright (1998), Clott (2004) }\end{array}$ \\
\hline Focus on core competence & $\begin{array}{l}\text { - To improve business focus } \\
\text { - To increase competitiveness } \\
\text { - To leverage the firm's skills and } \\
\text { resources } \\
\text { - To enhance customer satisfaction }\end{array}$ & $\begin{array}{l}\text { Prahalad and Hamel (1990), Quinn } \\
\text { and Hilmer (1994), Weerakkody et } \\
\text { al. (2003) }\end{array}$ \\
\hline Flexibility enhancement & $\begin{array}{l}\text { - To reduce constraints of } \\
\text { organization’s own production } \\
\text { capacity } \\
\text { - To convert fixed costs to variable } \\
\text { costs } \\
\text { - To increase responsiveness to } \\
\text { market change } \\
\text { - To reduce risks }\end{array}$ & $\begin{array}{l}\text { Quinn and Hilmer (1994), Corbett } \\
\text { (1998), Embleton and Wright } \\
\text { (1998), Razzaque and Sheng } \\
\text { (1998), Kakabadse and Kakabadse } \\
\text { (2000), Jennings (2002), Lynch } \\
\text { (2004) }\end{array}$ \\
\hline Environmental factors & Objectives or anticipated outcomes & Authors \\
\hline IT development & $\begin{array}{l}\text { - To meet increasing demand for } \\
\text { new information systems and } \\
\text { resources more efficiently and } \\
\text { economically }\end{array}$ & Lynch (2004) \\
\hline Globalization & $\begin{array}{l}\text { - To help companies gain global } \\
\text { competitive advantage }\end{array}$ & Clott (2004) \\
\hline Capability of supplier & $\begin{array}{l}\text { - To enable partnering to improve } \\
\text { service quality and customer } \\
\text { service and increase competitive } \\
\text { advantage }\end{array}$ & Jennings (2002) \\
\hline
\end{tabular}

Although there are good reasons to outsource, a number of potential obstacles and problems associated with outsourcing are also recognized. There is evidence that outsourcing does not reduce costs as expected in some cases (Beaumont and Sohal, 2004; Gonzales et al., 2005). As summarized in Table II, loss of control (Blumberg, 1998; Razzaque and Sheng, 1998; Lankford and Parsa, 1999; Kakabadse and Kakabadse, 2000; Claver et al., 2002; Lynch, 2004), loss of critical skills (Quinn and Hilmer, 1994; Jennings, 2002; Beaumont and Sohal, 2004), inadequate capabilities of service providers (Razzaque and Sheng, 1998; AlQirim, 2003), loss of flexibility (Embleton and Wright, 1998; Beaumont and Sohal, 2004), failure to realize the hidden costs generated by the contract (Palvia, 1995; Kakabadse and Kakabadse, 2000; Gonzalez et al., 2005), difficulty in obtaining organizational support (Razzaque and Sheng, 1998), indecisiveness on which activities to outsource (Lankford and Parsa, 1999), inadequacy of cost and benefit analysis systems (McIvor and Humphreys, 2000), fear of job loss (Razzaque and Sheng, 1998), and damage to morale of existing workers (Embleton and Wright, 1998), etc. are among the commonly cited inhibitors to outsourcing. 
Table II Main obstacles and problems of outsourcing

\begin{tabular}{|l|l|l|}
\hline \multicolumn{1}{|c|}{ Obstacles and problems } & \multicolumn{1}{|c|}{ Impacts } & \multicolumn{1}{c|}{ Authors } \\
\hline Loss of control & $\begin{array}{l}\text { - Loss of core competence } \\
\text { - Risks of alienating customers }\end{array}$ & $\begin{array}{l}\text { Blumberg (1998), Lonsdale and } \\
\text { Cox (2000) }\end{array}$ \\
\hline Loss of critical skills & $\begin{array}{l}\text { - Loss of competitive advantage } \\
\text { - Increased number of competitors }\end{array}$ & $\begin{array}{l}\text { Quinn and Hilmer (1994), Jennings } \\
\text { (2002), Beaumont and Sohal } \\
\text { (2004) }\end{array}$ \\
\hline $\begin{array}{l}\text { Inadequate capabilities of } \\
\text { service provider }\end{array}$ & $\begin{array}{l}\text { - Loss of competitive advantage } \\
\text { - Loss of market share }\end{array}$ & Jennings (2002) \\
\hline $\begin{array}{l}\text { Loss of flexibility } \\
\text { Failure to realize hidden costs } \\
\text { of contract }\end{array}$ & $\begin{array}{l}\text { - Reduced responsiveness } \\
\text { - Risks of alienating customers }\end{array}$ & $\begin{array}{l}\text { Embleton and Wright (1998), } \\
\text { Beaumont and Sohal (2004) }\end{array}$ \\
\hline $\begin{array}{l}\text { Difficulty in obtaining } \\
\text { organizational support }\end{array}$ & $\begin{array}{l}\text { Palvia (1995), Kakabadse and } \\
\text { Kakabadse (2000), Gonzalez et al. } \\
\text { (2005) }\end{array}$ \\
\hline $\begin{array}{l}\text { Indecisiveness on which } \\
\text { activities to outsource }\end{array}$ & - Increased chances of failure & Razzaque and Sheng (1998) \\
\hline $\begin{array}{l}\text { Inadequate cost and benefit } \\
\text { analysis systems }\end{array}$ & $\begin{array}{l}\text { - Lower return on investment } \\
\text { - Loss of competitive advantage }\end{array}$ & $\begin{array}{l}\text { Lankford and Parsa (1999) } \\
\text { Fear of job loss }\end{array}$ \\
\hline
\end{tabular}

In recent years, the Chinese government has designated logistics as a strategic industry and invested heavily in improving infrastructure such as nationwide multi-modal transportation networks and large-scale modernized logistics and distribution centers (Trunick, 2003). The accession of China to the WTO has opened up several of her transportation and logistics sectors to direct foreign participation (Hertzell, 2001). Consequently, more intensive competition between Chinese and foreign companies, both inside and outside China, is expected (Agarwal and Wu, 2004). Meanwhile, the pattern of ownership of Chinese enterprises has gradually shifted from absolute dominancy of the stateowned enterprises to co-existence of ownership in hybrid forms (Chen and Huang, 2005). The increase in competition and growing awareness of the role of logistics lead more companies to exploit the potential of outsourcing. Manufacturers are increasingly looking for logistics solutions to move their goods to the fast-expanding consumer markets. Further, the trend towards consolidation in many of the industries and the emergence of national chains are also creating demand for outsourcing (Hertzell, 2001). Table III summarizes the key factors that are expected to stimulate the growth of outsourcing in China.

Table III Key factors stimulating the growth of outsourcing in China

\begin{tabular}{|l|l|l|}
\hline \multicolumn{1}{|c|}{ Key factors } & \multicolumn{1}{|c|}{ Descriptions } & \multicolumn{1}{c|}{ Results } \\
\hline Government initiatives & $\begin{array}{l}\text { - Investment in logistics } \\
\text { infrastructure }\end{array}$ & $\begin{array}{l}\text { - Has encouraged domestic companies to } \\
\text { outsource a greater percentage of their } \\
\text { logistics needs }\end{array}$ \\
\hline Entry to WTO & $\begin{array}{l}\text { - High-quality foreign 3PL providers } \\
\text { entering Chinese logistics market } \\
\text { - Relaxation of regulations } \\
\text { - Increased competition }\end{array}$ & $\begin{array}{l}\text { - Has enabled companies to outsource } \\
\text { more functions } \\
\text { - Has encouraged more companies to } \\
\text { exploit outsourcing potential }\end{array}$ \\
\hline $\begin{array}{l}\text { Economic reform and } \\
\text { development }\end{array}$ & - Enlargement of consumer market & $\begin{array}{l}\text { - Has increased demand for logistics } \\
\text { solution }\end{array}$ \\
\hline $\begin{array}{l}\text { Consolidation in } \\
\text { industries and } \\
\text { emergence of national } \\
\text { chains }\end{array}$ & $\begin{array}{l}\text { - Creation of large and more } \\
\text { complex players }\end{array}$ & $\begin{array}{l}\text { Has increased need for transportation } \\
\text { and logistics solutions }\end{array}$ \\
\hline
\end{tabular}


Despite the favorable factors, China's 3PL industry is still in its early stage of development. Compared to an overall transportation and logistics expenditures of US\$230 billion in 2001, outsourced logistics was estimated to be just under US\$4.8 billion or about 2 percent (Kadar and Huang, 2002). Poor infrastructure and entrenched regulatory environment are among the obstacles that hinder the development of 3PL. Although the Chinese government has made significant investments in the logistics sector in recent years, there is little integration of transportation networks, information technology, warehousing, and distribution facilities. Meanwhile, regulations exert tight controls on business activities at provincial level, which hinders the creation of national networks (Kerr, 2005). Therefore, it is difficult for 3PLs in China to fully meet the requirements of their clients. Table IV summarizes the key challenges for the Chinese logistics industry.

Table IV Key challenges for the Chinese logistics industry

\begin{tabular}{|c|c|c|}
\hline Challenges & Problems & Impacts \\
\hline Poor Infrastructure & $\begin{array}{l}\text { - Lack of effective transportation } \\
\text { networks } \\
\text { - Lack of IT infrastructure } \\
\text { - Little integration of transportation } \\
\text { networks, IT, warehousing, and } \\
\text { distribution facilities }\end{array}$ & $\begin{array}{l}\text { - Higher transportation costs } \\
\text { - Lack of reliability in pick-up and } \\
\text { delivery time }\end{array}$ \\
\hline Regulation issues & - Local protection & $\begin{array}{l}\text { - Ha restrained the development of } \\
\text { national service networks } \\
\text { - Has made it difficult for 3PLs in China } \\
\text { to fully meet the requirements of their } \\
\text { clients }\end{array}$ \\
\hline Finding qualified staff & $\begin{array}{l}\text { - Lack of logistics training programs } \\
\text { - Lack of high-quality providers with } \\
\text { the scope and scale to fully meet } \\
\text { customers' requirements }\end{array}$ & $\begin{array}{l}\text { - Shippers have little confidence in the } \\
\text { service levels of 3PLs } \\
\text { - Difficult to find good providers that can } \\
\text { deliver high quality and consistent } \\
\text { services across geographical regions }\end{array}$ \\
\hline
\end{tabular}

\section{Methodology}

This research uses a case study approach which means in-depth investigation of a contemporary phenomenon within its real-life context (Yin, 2003). The case study approach lends itself to a concentrated focus on the topic and allows a combination of multiple sources of evidence which enables the researcher to capture and place the complex reality under scrutiny (Saunders et al., 2003; Yin, 2003). Despite its ability to explore the complexity of an issue, however, case study approach does have its limitation in the generalization of results. This is mainly because case studies are usually based on small samples for in-depth study. Inherent to most interview surveys, variations in position, knowledge level, experience, etc. of the participants in structured interviews also render generalization of survey result difficult.

Nevertheless, case study research is a commonly adopted strategy in the study of outsourcing decision (Benson and Leronimo, 1996; Fill and Visser, 2000; Bolumole, 2001; McIvor, 2003). The use of case study approach in this study ensures an in-depth exploration of the research question and enables the researchers to gain an insight into the real motivations behind the companies engaged in outsourcing, the obstacles and problems in the outsourcing process, and their impacts on the organization performance. In order to make the findings representative, companies chosen for this study were selected across a wide range of industries and from those which are currently involved in outsourcing.

Six in-depth, semi-structured face-to-face interviews, each lasting for about two hours, were carried out to collect primary data for this research. Judgment sampling was employed to 
select sampling units of this study (Boyce, 2003; Zikmund, 2003). Survey respondents were selected from companies of three major ownership types in China, namely, state-, private-, and foreign-owned (The Institute of World Economics and Politics, 2005). Six persons, one from each of the six companies including departmental and senior managers directly participated in or responsible for making outsourcing decision, were interviewed. Secondary data such as company documents, reports, and web sites were also gathered to better understand the background of the responding organizations and their outsourcing performance. Tables V and VI summarize the profiles of the six companies studied and their outsourced activities, respectively. The name of each responding company has been coded to preserve anonymity.

Table V Profiles of the six companies studied

\begin{tabular}{|c|c|c|c|c|c|c|c|}
\hline $\begin{array}{l}\text { Comp } \\
\text { any }\end{array}$ & $\begin{array}{l}\text { Ownership } \\
\text { type }\end{array}$ & $\begin{array}{l}\text { Industry } \\
\text { type }\end{array}$ & $\begin{array}{l}\text { Establish } \\
\text { ment }\end{array}$ & Location & $\begin{array}{l}\text { Annual } \\
\text { company } \\
\text { revenue } \\
\end{array}$ & $\begin{array}{l}\text { No. of } \\
\text { employees }\end{array}$ & $\begin{array}{l}\text { Position of } \\
\text { interviewee }\end{array}$ \\
\hline A & $\begin{array}{l}\text { State- } \\
\text { owned }\end{array}$ & $\begin{array}{l}\text { Textile } \\
\text { import and } \\
\text { export } \\
\text { company }\end{array}$ & 1951 & Beijing & $\begin{array}{l}\text { US\$1.45 } \\
\text { billion in } \\
2004\end{array}$ & 700 & $\begin{array}{l}\text { General } \\
\text { manager of a } \\
\text { strategic } \\
\text { business unit }\end{array}$ \\
\hline B & $\begin{array}{l}\text { State- } \\
\text { owned }\end{array}$ & $\begin{array}{l}\text { Agricultural } \\
\text { product and } \\
\text { food import } \\
\text { and export } \\
\text { company }\end{array}$ & 1952 & Beijing & $\begin{array}{l}\text { US\$2.7 } \\
\text { billion in } \\
2004\end{array}$ & 1,000 & $\begin{array}{l}\text { IT department } \\
\text { manager }\end{array}$ \\
\hline $\mathrm{C}$ & $\begin{array}{l}\text { Private- } \\
\text { owned }\end{array}$ & $\begin{array}{l}\text { Electronics } \\
\text { and home } \\
\text { appliance } \\
\text { retailer }\end{array}$ & 1982 & Beijing & $\begin{array}{l}\text { Eight } \\
\text { billion } \\
\text { Yuan in } \\
2004\end{array}$ & 15,000 & $\begin{array}{l}\text { General } \\
\text { manager of a } \\
\text { chain store }\end{array}$ \\
\hline $\mathrm{D}$ & $\begin{array}{l}\text { Private- } \\
\text { owned }\end{array}$ & $\begin{array}{l}\text { Cultural } \\
\text { business } \\
\text { company }\end{array}$ & 2000 & Beijing & $\begin{array}{l}\text { Ten } \\
\text { million } \\
\text { Yuan in } \\
2004\end{array}$ & 10 & $\begin{array}{l}\text { General } \\
\text { manager of the } \\
\text { company }\end{array}$ \\
\hline$E$ & $\begin{array}{l}\text { Foreign- } \\
\text { owned }\end{array}$ & $\begin{array}{l}\text { Measuremen } \\
\text { t product } \\
\text { manufacturer }\end{array}$ & $\begin{array}{l}1985 \\
\text { (entered } \\
\text { China) } \\
\end{array}$ & Beijing & $\begin{array}{l}\text { US\$1 } \\
\text { billion in } \\
2004 \\
\end{array}$ & 2,000 & $\begin{array}{l}\text { Logistics } \\
\text { department } \\
\text { manager }\end{array}$ \\
\hline $\mathrm{F}$ & $\begin{array}{l}\text { Foreign- } \\
\text { owned }\end{array}$ & $\begin{array}{l}\text { Soft drink } \\
\text { manufacturer }\end{array}$ & $\begin{array}{l}1979 \\
\text { (entered } \\
\text { China) }\end{array}$ & Shanghai & $\begin{array}{l}\text { US\$343 } \\
\text { million in } \\
2004\end{array}$ & 600 & $\begin{array}{l}\text { Human } \\
\text { resource (HR) } \\
\text { department } \\
\text { manager }\end{array}$ \\
\hline
\end{tabular}


Table VI Outsourced activities of the six companies studied

\begin{tabular}{|c|c|c|}
\hline Company & Main activities outsourced & Starting time \\
\hline $\mathrm{A}$ & $\begin{array}{l}\text { - } 100 \text { percent transportation } \\
\text { - } 100 \text { percent warehousing } \\
\text { - } 100 \text { percent freight and charge settlement, customs declaration, } \\
\text { inspection, and insurance } \\
\text { - IT outsourcing under planning in } 2005\end{array}$ & 1983 \\
\hline B & $\begin{array}{l}\text { - } 100 \text { percent transportation } \\
\text { - } 100 \text { percent warehousing } \\
\text { - } 10 \text { percent IT support } \\
\text { - There is plan to outsource more IT functions } \\
\end{array}$ & 1982 \\
\hline $\mathrm{C}$ & $\begin{array}{l}\text { - } 90 \text { percent transportation and warehousing } \\
\text { - } 100 \text { percent deployment of seasonal workforce } \\
\text { - } 90 \text { percent customer services including returns handling, installation, } \\
\text { and maintenance work } \\
\text { - } 100 \text { percent cleaning and catering } \\
\text { - IT outsourcing under planning in } 2005\end{array}$ & 1999 \\
\hline $\mathrm{D}$ & $\begin{array}{l}\text { - } 100 \text { percent printing } \\
\text { - } 100 \text { percent cleaning and catering } \\
\text { - There is plan to outsource other functions }\end{array}$ & 2000 \\
\hline $\mathrm{E}$ & $\begin{array}{l}\text { - } 100 \text { percent transportation and warehousing management } \\
\text { - } 40 \text { percent training } \\
\text { - } 100 \text { percent renting of personal computers } \\
\text { - } 30 \text { percent maintenance work } \\
\text { - } 100 \text { percent cleaning and catering } \\
\text { - There is plan to outsource more activities such as HR, accounting, } \\
\text { administration, and manufacturing }\end{array}$ & 1999 \\
\hline F & $\begin{array}{l}\text { - } 100 \text { percent transportation and } 90 \text { percent warehousing } \\
\text { - } 6 \text { percent IT services } \\
\text { - } 30 \text { percent training } \\
\text { - } 100 \text { percent renting of vehicles for company use } \\
\text { - } 100 \text { percent cleaning and catering } \\
\text { - There is plan to outsource more activities such as IT, HR, } \\
\text { accounting, and administration }\end{array}$ & 1990 \\
\hline
\end{tabular}

Content analysis, which categorizes responses from individual respondents into categories of themes or patterns, was used to facilitate within- and cross-case comparisons (Carson et al., 2001; Lukas et al., 2004). The within-case analysis identified issues, some are unique to the individual case and some are common to all six companies. Focusing on the more significant issues, the cross-case analysis compared and contrasted the findings across the six cases studied. Also, a comparison with the observations in Western developed countries was made to identify similarities and differences in the key drivers and obstacles of outsourcing between developed countries and China.

\section{Results}

The findings elicited from the six case studies indicate that the common drivers of outsourcing can be broadly grouped into three categories: economic, strategic, and environmental. Successful outsourcing helps the six companies achieve various objectives resulting in cost saving or efficiency improvement which ultimately leads to a competitive advantage. The case studies also reveal that there are various obstacles and problems of outsourcing in China, such as the lack of capable service providers, which pose challenges to companies planning to outsource. To a certain extent, these challenges limit the scope of outsourcing and its pace of development in China. The key findings drawn from the six case studies are summarized as follows: 


\section{Drivers of outsourcing}

(1) Table VII lists the prominent reasons for outsourcing of the six responding companies. Among the identified drivers, some are considered more important than the others with one company (Company B) ranked the most important two. All the companies consider economic factors pivotal in the outsourcing decision process. "Cost reduction" or "cost saving" is the primary reason for outsourcing of all the six companies except Company B which ranks it as the second most important reason. This finding concurs with a wealth of literature which suggests that most outsourcing deals are driven by a desire to reduce cost (Corbett, 1996; Fan, 2000; Kakabadse and Kakabadse, 2000; Zhu et al., 2001; Lynch, 2004).

(2) For all the six companies studied, outsourcing enables them to focus on their core competence, to increase their flexibility, and to enable them to access to expertise and technology.

(3) "Capital investment reduction" is also the most prominent reason for outsourcing of Companies C, D, E, and F which expect to reduce capital investment in transportation, warehousing, manufacturing, IT, and employees in order to release capital for core business and to improve return on assets. This supports Razzaque and Sheng's (1998) view that outsourcing reduces the need to invest capital in facilities, equipment, IT and manpower. The findings also suggest that for private- and foreign-owned companies which were established or entered China as a result of the Chinese economic reform, reducing capital investment and cost is an important part of their survival strategies in order to enhance competitiveness and flexibility.

(4) All six companies choose to outsource their business activities in order to focus on their core competence and increase flexibility. This agrees with the literature which suggests that organizations should outsource activities for which they do not have a critical strategic need or special capability, and focus their attention on core competence to increase customer value (Lankford and Parsa, 1999; Jennings, 2002).

(5) "To accelerate re-engineering benefits" is one of the strategic factors that influence the decisions of Companies A and B to outsource while "to facilitate market penetration" is a strategic concern of outsourcing for Companies C, E, and F. This finding supports Rothery and Robertson's (1995) and Corbett's (1998) view that re-engineering gives companies the opportunity to consider outsourcing as one of the tools that they can use in the new process to improve company performance and reduce operational costs.

(6) All six companies consider outsourcing an effort to increase flexibility in the utilization of transportation and warehousing capacity and to reduce risks in IT investment. These are consistent with the findings from surveys in the US and Europe (Rabinovich et al., 1999; Claver et al., 2002). Outsourcing is also used to provide seasonal workforce and to overcome constraints in production capacity. These also agree with previous research findings by Embleton and Wright (1998) and Kakabadse and Kakabadse (2000). The study also reveals that outsourcing has been used to convert a largely fixed cost business to one with variable costs in which expenses can change according to the business climate. This finding is also in agreement with that of McFarlan and Nolan (1995).

(7) "To facilitate market penetration" is regarded as a strategic reason for outsourcing by Companies C, E, and F. Although "to facilitate market penetration" is not principally described as a strategic factor in the literature, this finding is in line with Lynch's (2004) view on global outsourcing that it can help organizations enter new markets quickly without heavy initial investments and get geographically closer to customers to enhance responsiveness to changing customer needs. 
Table VII Drivers of outsourcing considered by the six companies studied

\begin{tabular}{|c|c|c|c|c|c|c|}
\hline $\begin{array}{l}\text { Drivers of } \\
\text { outsourcing }\end{array}$ & $\begin{array}{c}\text { Company A } \\
\text { (Case 1) }\end{array}$ & $\begin{array}{c}\text { Company B } \\
\text { (Case 2) }\end{array}$ & $\begin{array}{c}\text { Company } \\
\text { C } \\
\text { (Case 3) }\end{array}$ & $\begin{array}{c}\text { Company D } \\
\text { (Case 4) }\end{array}$ & $\begin{array}{c}\text { Company E } \\
\text { (Case 5) }\end{array}$ & $\begin{array}{c}\text { Company } F \\
\text { (Case 6) }\end{array}$ \\
\hline $\begin{array}{l}\text { Cost } \\
\text { reduction }\end{array}$ & $\begin{array}{c}\sqrt{ } \text { (most } \\
\text { important) }\end{array}$ & & $\begin{array}{c}\sqrt{ } \text { (most } \\
\text { important) }\end{array}$ & & $\begin{array}{c}\sqrt{ } \text { (most } \\
\text { important) }\end{array}$ & $\begin{array}{c}\sqrt{ } \text { (most } \\
\text { important) }\end{array}$ \\
\hline Cost saving & & $\begin{array}{l}\sqrt{ }\left(2^{\text {nd }} \text { most }\right. \\
\text { important })\end{array}$ & & $\begin{array}{c}\sqrt{ } \text { (most } \\
\text { important) }\end{array}$ & & \\
\hline $\begin{array}{l}\text { Capital } \\
\text { investment } \\
\text { reduction }\end{array}$ & & & $\begin{array}{c}\sqrt{ }(\text { most } \\
\text { important) }\end{array}$ & $\begin{array}{c}\sqrt{ }(\text { most } \\
\text { important) }\end{array}$ & $\begin{array}{l}\sqrt{ }(\text { most } \\
\text { important) }\end{array}$ & $\begin{array}{c}\sqrt{ }(\text { most } \\
\text { important) }\end{array}$ \\
\hline $\begin{array}{l}\text { To accelerate } \\
\text { re- } \\
\text { engineering } \\
\text { benefits }\end{array}$ & $\sqrt{ }$ & $\sqrt{ }$ & & & & \\
\hline $\begin{array}{l}\text { To focus on } \\
\text { core } \\
\text { competence }\end{array}$ & $\sqrt{ }$ & $\sqrt{ }$ & $\sqrt{ }$ & $\sqrt{ }$ & $\sqrt{ }$ & $\sqrt{ }$ \\
\hline $\begin{array}{l}\text { To increase } \\
\text { flexibility }\end{array}$ & $\sqrt{ }$ & $\sqrt{ }$ & $\sqrt{ }$ & $\sqrt{ }$ & $\sqrt{ }$ & $\sqrt{ }$ \\
\hline $\begin{array}{l}\text { To facilitate } \\
\text { market } \\
\text { penetration }\end{array}$ & & & $\sqrt{ }$ & & $\sqrt{ }$ & $\sqrt{ }$ \\
\hline $\begin{array}{l}\text { Capability of } \\
\text { supplier }\end{array}$ & $\sqrt{ }$ & $\sqrt{ }$ & $\sqrt{ }$ & $\sqrt{ }$ & $\sqrt{ }$ & $\sqrt{ }$ \\
\hline $\begin{array}{l}\text { IT } \\
\text { development } \\
\text { (Access to } \\
\text { expertise / } \\
\text { technology) }\end{array}$ & $\sqrt{ }$ & $\begin{array}{l}\sqrt{ }\left(1^{\text {st }} \text { most }\right. \\
\text { important })\end{array}$ & $\sqrt{ }$ & $\sqrt{ }$ & $\sqrt{ }$ & $\sqrt{ }$ \\
\hline
\end{tabular}

Note: Drivers marked with " $\checkmark$ ' are considered prominent reasons for outsourcing by the responding companies

Problems and obstacles of outsourcing

(1) In general, the organizations interviewed are satisfied with the service providers' performance. However, none of them have achieved the desired benefits from outsourcing. All of them have not realized the expected cost reduction in areas of transportation, warehousing, administration, and operation. These findings are similar to the results of a survey by PA Consulting Group (1996) that few organizations have achieved high levels of benefits from outsourcing objectives (cited in Fan, 2000). All the six companies have encountered some obstacles and problems in the outsourcing process, which are summarized in Table VIII. These findings support many researchers' view that there are daunting challenges hindering the development of 3PL industry and the demand for outsourcing in China (Hertzell, 2001; Trunick, 2003; Kerr, 2005).

(2) "Lack of capable service providers" is the major problem of outsourcing identified, which includes inability to provide effective transportation networks, poor transportation tools, old-designed warehousing facilities, lack of qualified staff, and lack of IT capability. These findings support Mercer's (cited in Kadar and Huang, 2002) conclusion that not many logistics providers in China are considered reliable, high-quality providers with the scope and scale to fully meet customers' requirements.

(3) Another problem cited by the six companies interviewed is "loss of control" over the outsourced activity, which is also considered one of the most commonly cited inhibitors to outsourcing in the literature (Blumberg, 1998; Razzaque and Sheng, 1998; Lankford and Parsa, 1999).

(4) "Poor transportation and IT infrastructure" and "local protection regulations" are also regarded as major obstacles to outsourcing, which are not viewed as critical problems in 
Western developed countries. In addition, "local protection regulations" lead to the increase in logistics cost and damage rate, thus reduce company profit margins. They also limit the choices of companies in selecting their desired suppliers. These findings support the results of several studies (Hertzell, 2001; Trunick, 2003; Kerr, 2005) that poor infrastructure and entrenched regulatory environment are two of the daunting challenges that will hinder the development of 3PL industry in China.

(5) The six companies studied have no comparison of pre- and post-outsourcing costs in areas like administration, operation, and office expenses. This is similar to Fan's (2000) finding from a survey of the British companies that the majority of respondents have no clear post-outsourcing measurement.

(6) Though widely considered as a major obstacle of outsourcing in the literature, "loss of critical skills" is not evident in this study. One possible explanation is that the six companies interviewed are still having a relatively small extent of outsourcing at this stage and the majority of the outsourced activities are "peripheral".

Table VIII Major obstacles and problems of outsourcing encountered by the six companies studied

\begin{tabular}{|c|c|}
\hline Major obstacles and problems & Challenges \\
\hline Lack of capable service providers & $\begin{array}{l}\text { - Less than expected service quality } \\
\text { - Failure in realizing expected cost reduction or capital } \\
\text { investment reduction } \\
\text { - Hindrance to further outsourcing of activities }\end{array}$ \\
\hline Loss of control & $\begin{array}{l}\text { - Inconsistent service quality } \\
\text { - Inefficiency in communication }\end{array}$ \\
\hline Poor transportation and IT infrastructure & $\begin{array}{l}\text { - Higher logistics costs } \\
\text { - Unreliability in pickup and delivery time } \\
\text { - Higher rate of loss and damage of goods } \\
\text { - Poor customer service }\end{array}$ \\
\hline Local protection regulations & $\begin{array}{l}\text { - Higher logistics cost and damage rate } \\
\text { - Limitation in choices of suppliers }\end{array}$ \\
\hline Lack of overall post-outsourcing review & $\begin{array}{l}\text { - Failure in knowing if the outsourcing process is working as } \\
\text { planned } \\
\text { - Failure in identifying areas of improvements or changes }\end{array}$ \\
\hline
\end{tabular}

\section{Comparison between Western developed countries and China}

The findings also show that there are similarities and differences between the key outsourcing drivers and obstacles in Western developed countries and China. As shown in Table IX, cost reduction, cost saving, and capital investment reduction are the main economic reasons for outsourcing both in China and in developed countries. Organizations in China and developed countries alike use outsourcing to achieve certain strategic goals such as to accelerate reengineering benefits, to focus on core competence, and to increase flexibility. However, to facilitate market penetration is also cited as a strategic reason for outsourcing in China but not significantly stressed in the developed countries. This difference is understandable as companies in developing countries are generally young and fast-developing striving to occupy the maximum market share. The findings also reveal that environment factors, such as IT development and capability of supplier, can influence organizations' decisions to outsource in China, which is similar to the situation in developed countries. However, the study results indicate that globalization, which is often cited as an environment factor that facilitates the greater use of outsourcing in developed countries, is currently not a major concern of organizations in China in making their outsourcing decisions. This suggests that the focus of the companies in China is still placed on capitalizing the huge potential consumer market in the mainland. The findings further reveal that organizations in China are facing certain obstacles and problems in the outsourcing process, of which lack of capable service providers, 
loss of control, poor transportation and IT infrastructure, local protection regulations, and lack of overall post-outsourcing measurement are the major ones. Although the literature indicates that Western developed countries also face many obstacles and problems in outsourcing, loss of control and loss of critical skills are the ones often stressed. This difference suggests that outsourcing in China is still in its infancy stage as observed by Trunick (2003).

Table IX Comparison of drivers and obstacles of outsourcing between China and Western developed countries

\begin{tabular}{|c|c|c|}
\hline $\begin{array}{l}\text { Drivers of } \\
\text { outsourcing }\end{array}$ & China & Western developed countries \\
\hline $\begin{array}{l}\text { Economic } \\
\text { factors }\end{array}$ & $\begin{array}{l}\text { - Cost reduction } \\
\text { - Cost saving } \\
\text { - Capital investment reduction }\end{array}$ & $\begin{array}{l}\text { - Cost reduction } \\
\text { - Cost saving } \\
\text { - Capital investment reduction }\end{array}$ \\
\hline $\begin{array}{l}\text { Strategic } \\
\text { factors }\end{array}$ & $\begin{array}{l}\text { - To accelerate re-engineering } \\
\text { - To focus on core competence } \\
\text { - To increase flexibility } \\
\text { - To facilitate market penetration }\end{array}$ & $\begin{array}{l}\text { - To accelerate re-engineering } \\
\text { - To focus on core competence } \\
\text { - To increase flexibility }\end{array}$ \\
\hline $\begin{array}{l}\text { Environmental } \\
\text { factors }\end{array}$ & $\begin{array}{l}\text { - IT development } \\
\text { - Capability of supplier }\end{array}$ & $\begin{array}{l}\text { - IT development } \\
\text { - Capability of supplier } \\
\text { - Globalization } \\
\end{array}$ \\
\hline $\begin{array}{l}\text { Obstacles and } \\
\text { problems }\end{array}$ & $\begin{array}{l}\text { - Loss of control } \\
\text { - Lack of capable service providers } \\
\text { - Poor transportation and IT } \\
\text { infrastructure } \\
\text { - Local protection regulations } \\
\text { - Lack of overall post-outsourcing review }\end{array}$ & $\begin{array}{l}\text { - Loss of control } \\
\text { - Loss of critical skills }\end{array}$ \\
\hline
\end{tabular}

Note: Bolded items are those identified in China but not in Western developed countries. Italicized items are those found in Western developed countries but not in this study.

\section{Conclusion}

This paper has explored the key drivers of outsourcing and the main obstacles or problems faced by organizations in China. The findings indicate that economic, strategic, and environmental factors are the main drivers that motivate organizations in China to engage in outsourcing. They are similar to those identified in the Western developed countries. For economic factors, cost reduction, cost saving, and capital investment reduction are the main concerns. This is in agreement with the literature reporting the situation in developed countries (Razzaque and Sheng, 1998; Kakabadse and Kakabadse, 2000; Claver et al., 2002; Lynch, 2004).

The findings also show that organizations in China have taken some strategic considerations when making outsourcing decisions. They include the use of outsourcing to accelerate re-engineering benefits, to focus on core competence, and to increase flexibility. This is also in agreement with the findings in the literature reporting the situation in developed countries (Quinn and Hilmer, 1994; Corbett, 1998; Mazziwi, 2002). Meanwhile, to facilitate market penetration is also cited as a strategic reason for outsourcing in China but not in developed countries.

The findings further demonstrate that environmental factors such as IT development and capability of supplier can influence organizations' decisions to outsource in China, which is in agreement with the literature (Razzaque and Sheng, 1998; Lynch, 2004; Kakabadse and Kakabadse, 2005). However, the results indicate that globalization, which is often cited as an environmental factor that facilitates the greater use of outsourcing in developed countries, is not a major concern of organizations in China when making their outsourcing decisions. On 
the other hand, capability of service supplier in terms of service quality, availability of extensive domestic transportation network, financial strength, reputation, reliability, use of latest technology, price, and relationship with client, etc., are regarded as the most important considerations when it comes to the selection of a service provider.

The study also reveals that organizations in China have encountered some obstacles and problems in the outsourcing process, of which lack of capable service providers, loss of control, poor transportation and IT infrastructure, local protection regulations, and lack of overall post-outsourcing measurement are the major ones. Although the literature indicates that Western developed countries also face many obstacles and problems in outsourcing (Blumberg, 1998; Razzaque and Sheng, 1998; Lankford and Parsa, 1999; McIvor and Humphreys, 2000; Al-Qirim, 2003), loss of control and loss of critical skills are often cited as the major ones.

Based on the findings of this study, a framework for making outsourcing decisions in China is proposed in Figure 1. The framework suggests that organizations in China should consider both economic and strategic implications when making outsourcing decisions. From an economic perspective, companies may need to undertake a total cost analysis to identify and measure all the costs associated with the outsourcing of an activity so as to ensure costeffectiveness. In addition, outsourcing decisions should also be made from a strategic perspective and be fully integrated into the business planning process to achieve long-term success. A detailed evaluation of IT development and a careful analysis of the supplier's capability may also be required. In order to minimize the risk of failure, companies should also be aware of other potential problems such as impact on customer service level when deciding to outsource.

With heavy investment in logistics infrastructure and accelerated economic reform, business environment in China has become more and more dynamic. The entry of global logistics providers in the Chinese market will certainly encourage the use of 3PLs. Outsourcing will become one of the most effective business strategies for organizations in China to achieve cost-effective performance and long-term success. To fully investigate the impacts of outsourcing in this fast-changing economic climate, more studies are required to explore the best practices of outsourcing in China. To help determine the validity of the proposed framework proposed in this study, further research with a larger sample across a wider spectrum of industries and companies of different operating scales is, therefore, recommended. 


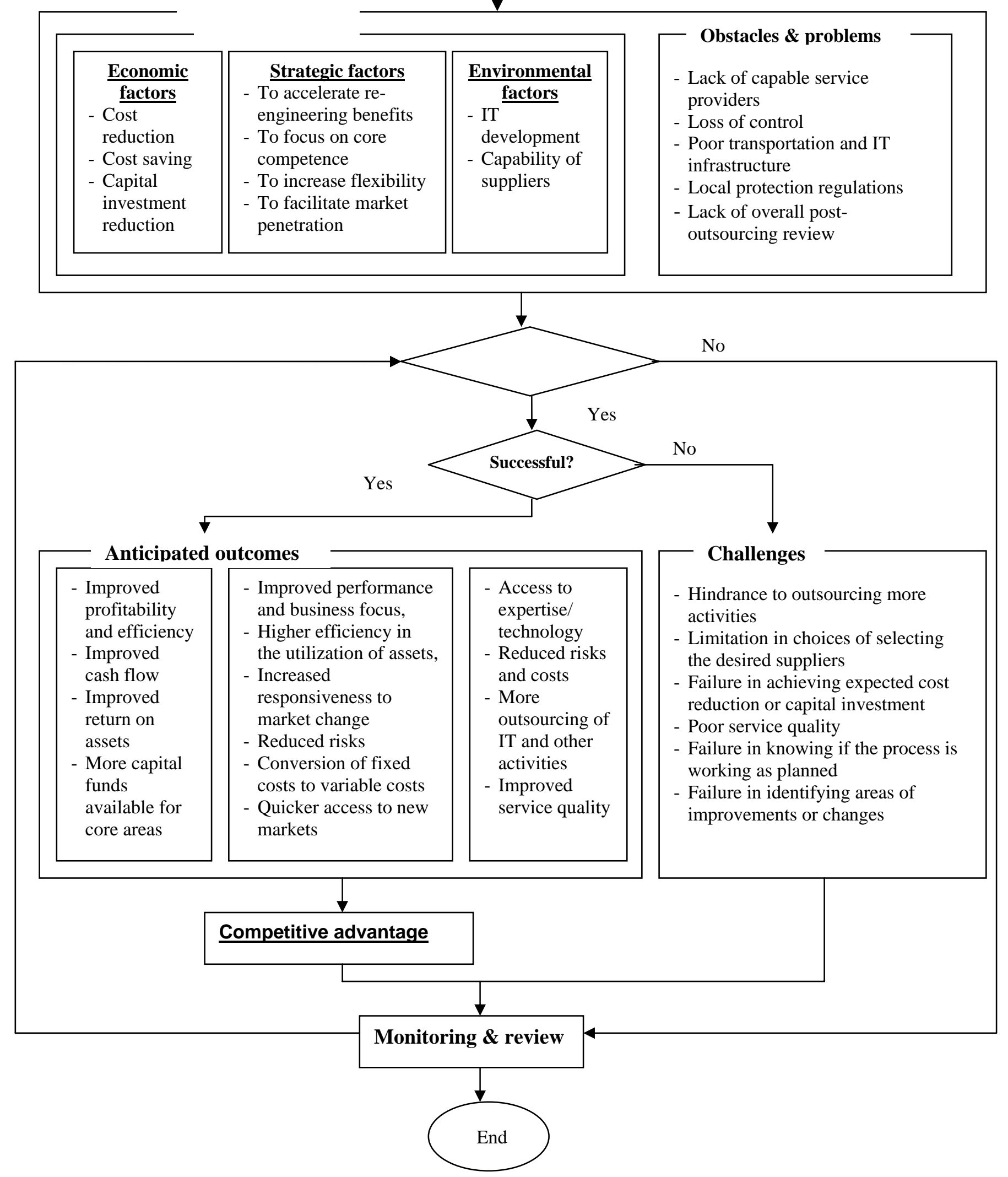

Figure 1 A proposed framework for making outsourcing decisions in China 


\section{Acknowledgements}

The authors would like to thank the six companies and their employees interviewed in this study for providing the detailed information. Their sincere thanks also go to the two anonymous reviewers for offering their valuable comments and suggestions on improving the paper.

\section{References}

Agarwal, J. and Wu, T. (2004), “China’s entry to WTO: global marketing issues, impact, and implications for China”, International Marketing Review, Vol. 21, No. 3, pp. 279-300.

Al-Qirim, N.A.Y. (2003), “The strategic outsourcing decision of IT and eCommerce: The case of small businesses in New Zealand'”, Journal of Information Technology Cases and Applications, Vol. 5, No. 3, pp. 32-56.

Beaumont, N. and Sohal, A. (2004), “Outsourcing in Australia”, International Journal of Operations \& Production Management, Vol. 24, No. 7, pp. 688-700.

Benson, J. and Leronimo, N. (1996), “Outsourcing decisions: evidence from Australia-based enterprises”, International Labour Review, Vol. 135, No. 1, pp. 59-73.

Blumberg, D.F. (1998), "Strategic assessment of outsourcing and downsizing in the service market”, Managing Service Quality, Vol. 8, No. 1, pp. 5-18.

Bolumole, Y.A. (2001), “The supply chain role of third-party logistics providers", International Journal of Logistics Management, Vol.12, No. 2, pp. 87-102.

Boyce J. (2003), Market Research in Practice, McGraw-Hill, Townsville.

Brown, A.S. (2005), “The China road”, Mechanical Engineering, Vol. 127, No. 3, pp. 36-40.

Cap Gemini, Georgia Institute of Technology, SAP, and DHL (2006), "Key findings of overall logistics outsourcing trends”, available at: http://3plstudy.com/?p=overall_logistics_outsourcing_trends (accessed May 22).

Carson, D., Gilmore, A., Perry, C. and Cronhaug, K. (2001), Qualitative Marketing Research, Sage, London.

Chen, J.G. and Huang, Q.J. (2005), “Comparison of governance structures of Chinese enterprises with different types of ownership", available at: http://unpan1.un.org/intradoc/groups/public/documents/APCITY/UNPAN003085.pdf (accessed July 15).

Claver, E., Gonzales, R., Gasco, J. and Llopis, J. (2002), "Information systems outsourcing: reasons, reservations and success factors", Logistics Information Management, Vol. 15, No. 4, pp. 294-308.

Clott, C.B. (2004), "Perspectives on global outsourcing and the changing nature of work", Business and Society Review, Vol. 109, No. 2, pp. 153-70. 
Corbett, M.F. (1996), “Outsourcing as a strategic tool”, Canadian Business Review, Vol. 23, No. 2, pp. 14-6.

Corbett, M.F. (1998), “Outsourcing: beyond buying services”, Facilities Design \& Management, Vol. 17, No. 1, pp. 40-3.

Emblemton, P.R. and Wright, P.C. (1998), “A practical guide to successful outsourcing”, Empowerment in Organizations, Vol. 6, No. 3, pp. 94-106.

Fan, Y. (2000), "Strategic outsourcing: evidence from British companies", Marketing Intelligence \& Planning, Vol. 18, No. 4, pp. 213-9.

Fill, C. and Visser, E. (2000), "The outsourcing dilemma: a composite approach to the make or buy decision”, Management Decision, Vol. 38, No. 1, pp. 43-50.

Forrest, W. (2005), “Analyzing the pros and cons of outsourcing to China”, Purchasing, Vol. 134, No. 2, pp. 17-8.

Gonzalez, R., Gasco, J. and Llopis, J. (2005), “Information systems outsourcing reasons in the largest Spanish firms”, International Journal of Information Management, Vol. 25, No. 2, pp. 117-36.

Hannon, J. (2005), “Outsourcing to China”, Orkus Taiwan, available at: http://www.orkusasia.com/ORKUS_Outsourcing_to_China.pdf (accessed April 8).

Hertzell, S. (2001), “China’s evolving logistics landscape”, available at: http://www.mckinsey.com/practices/operationsstrategyeffectiveness/supplychainmanagem ent/globalnetworks/pdf/China_Logistics.pdf (accessed April 9).

Jennings, D. (2002), "Strategic sourcing: benefits, problems and a contextual model”, Management Decision, Vol. 40, No. 1, pp. 26-34.

Kadar, M. and Huang, D. (2002), “The third party logistics market in China, opportunities and challenges”, paper presented at CLM 2002 Conference, San Francisco, September 30, and October 2, Mercer Management Consulting, available at: http://www.mercermc.com/defaultFLASH.asp?section=Perspectives\&path=Specialty/tran sport.htm\&tier (accessed April 8).

Kakabadse, N. and Kakabadse, A. (2000), “Critical review - Outsourcing: a paradigm shift”, The Journal of Management Development, Vol. 19, No. 8, pp. 670-728.

Kakabadse, A. and Kakabadse, N. (2005), "Outsourcing: current and future trends", Thunderbird International Business Review, Vol. 47, No. 2, pp. 183-204.

Kerr, J. (2005), “10 keys challenges for the Chinese logistics industry”, Logistics Management, Vol. 44, No. 2, pp. 64-7.

Lankford, W.M. and Parsa, F. (1999), “Outsourcing: a primer”, Management Decision, Vol.37, No. 4, pp. 310-6. 
Lieb, R.C. and Bentz, B.A. (2004), "The use of third-party logistics services by large American manufacturers: the 2003 survey”, Transportation Journal, Vol. 43, No. 3, pp. 24-33.

Lonsdale C. and Cox A. (2000), “The historical development of outsourcing: the latest fad?”, Industrial Management \& Data Systems, Vol. 100, No. 9, pp. 444-50.

Lukas, B.A., Hair, J.F., Bush, R.P. and Ortinau, D.J. (2004), Marketing Research, McGrawHill, Townsville.

Lynch, C.F. (2004), “Why outsource?”, Supply Chain Management Review, Vol. 8, No. 7, pp. 44-9.

Matteo, M.D. (2003), "Sourcing in China”, The China Business Review, Vol. 30, No.5, pp. 30-3.

Mazziwi, E. (2002), “Transformational outsourcing”, Business Strategy Review, Vol.13, No.3, pp.39-43.

McFarlan, F.W. and Nolan, R.L. (1995), "How to manage an IT outsourcing alliance”, Sloan Management Review, Vol.36, No. 2, pp. 9-23.

McIvor, R. (2003), “Outsourcing: insights from the telecommunications industry”, Supply Chain Management, Bradford, Vol. 8, No. 4, pp. 380-94.

McIvor, R.T. and Humphreys, P.K. (2000), “A case-based reasoning approach to the make or buy decision”, Integrated Manufacturing Systems, Vol. 11, No. 5, pp. 295-310.

PA Consulting Group (1996), Riding the Wave of Channel Substitution, PACG, London.

Palvia, P.C. (1995), “A dialectic view of information systems outsourcing: pros and cons”, Information \& Management, Vol. 29, No. 5, pp. 265-75.

Prahalad, C.K. and Hamel, G. (1990), “The core competence of the corporation”, Harvard Business Review, Vol. 68, No. 3, pp. 79-91.

Quinn, J.B. and Hilmer, F.G. (1994), "Strategic outsourcing”, Sloan Management Review, Vol. 35, No. 4, pp. 43-55.

Rabinovich, E., Windle, R., Dresner, M. and Corsi, T. (1999), "Outsourcing of integrated logistics functions - an examination of industry practices", International Journal of Physical Distribution \& Logistics Management, Vol. 29, No. 6, pp. 353-73.

Razzaque, M.A. and Sheng, C.C. (1998), "Outsourcing of logistics functions: a literature survey”, International Journal of Physical Distribution \& Logistics Management, Vol. 28, No. 2., pp. 89-107.

Richardson, H.L. (1990), “Explore outsourcing”, Transportation \& Distribution, Vol. 31, No. 7, pp. 16-20. 
Rothery, B. and Robertson, I. (1995), The Truth about Outsourcing, Gower Publishing Limited, Aldershot.

Saunders, M., Lewis, P. and Thornhill, A. (2003), Research Methods for Business Students, $3^{\text {rd }}$ ed., Prentice Hall, Upper Saddle River, NJ.

The Institute of World Economics and Politics (IWEP) (2005), "Comparison of governance structures of Chinese enterprises with different types of ownership", available at: http://www.iwep.org.cn/wec/english/articles/2001_06/6chenjiagui.htm (accessed July 6).

Trunick, P.A. (1989), “Outsourcing: a single source for many talents”, Transportation \& Distribution, Vol. 30, No. 7, pp. 20-3.

Trunick, P.A. (2003), "Logistics links are critical in China”, Transportation \& Distribution, Vol. 44, No. 8, pp. 50-3.

Weerakkody, V., Curries, W.L. and Ekanayahe, Y. (2003), "Re-engineering business processes through application service providers”, Business Process Management Journal, Vol. 9, No. 6, pp. 776-94.

Welson, R. (1996), “It’s hard to buck the outsourcing tide”, PC Week, 15 July, p.1.

Yin, R.K. (2003), Case Study Research - Design and Methods, 3rd ed., Sage, Thousand Oaks, CA.

Zhu, Z.W., Hsu, .K. and Lillie, J. (2001), “Outsourcing - a strategic move: the process and the ingredients for success”, Management Decision, Vol. 39, No. 5, pp. 373-8.

Zikmund, W.G. (2003), Essentials of Marketing Research, $2^{\text {nd }}$ ed., Thomson, London. increases from $\$ 3$ to $\$ 4$ ? Why? 